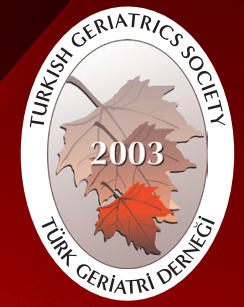

Turkish Journal of Geriatrics DOI: 10.31086/tjgeri.2019.107 2019; 22(3): 315-323

- Selçuk KAYA ${ }^{1}$

_ Önder ALTIN ${ }^{1}$ iD

CORRESPONDANCE

Selçuk KAYA

S.B.University Dr.Lutfi Kirdar Kartal Education

and Research Hospital, General Surgery,

Istanbul, Turkey.

Phone: +905052305952

e-mail: selcukkaya_36@hotmail.com

Received: 17/05/2019

Accepted: 08/08/2019

S.B.University Dr.Lutfi Kirdar Kartal Education and Research Hospital, General Surgery, Istanbul, Turkey.
RESEARCH

\section{EFFECT OF AGE ON ANASTOMOTIC LEAKAGE AND RELATED MORTALITY FOLLOWING COLORECTAL CANCER SURGERY}

\section{Abstract}

Purpose: The present study aimed to investigate the correlation between age and anastomotic leakage and leak-related mortality following colorectal cancer surgery.

Material and Method: Data of patients who underwent elective resection and anastomosis for colorectal cancer between January 2013 and December 2018 were retrospectively evaluated. Patients were divided into two groups: patients aged $<65$ years (Group 1) and those aged $\geq 65$ years (Group 2). Demographic characteristics, perioperative risks, diseased colonic segment, neoadjuvant chemoradiotherapy and surgical procedure (laparoscopic/open) were evaluated between both groups. The primary endpoint of the study was the development of anastomotic leakage within 30 days postoperatively. The secondary endpoint was the leakrelated mortality within 30 days postoperatively.

Results: The study included 358 patients; $60.6 \%$ of these were male and $39.4 \%$ were female, and mean age was $65.9 \pm 12.33$ years. The rate of anastomotic leakage was $5.6 \%(n=9)$ in Group 1 and $5.1 \%(n=10)$ in Group $2(p=0.283)$. Overall leak-related mortality was $1.95 \%$. The leak-related mortality was $0.6 \%$ in Group 1 and $3.06 \%$ in Group 2 ( $p=0.043$ ).

Conclusion: Our results demonstrate that age is not a risk factor for anastomotic leakage following colorectal cancer surgery; however, there is an increased mortality following anastomotic leakage in elderly patients.

Keywords: Anastomotic leakage; Aged; Colorectal cancer; Mortality

ARAŞTIRMA

\section{YAŞIN KOLOREKTAL KANSER CERRAHISI SONRASI ANASTOMOZ KAÇAĞI VE BUNA BAĞLI GELIŞEN MORTALITE ÜZERINE ETKISI $\ddot{O}_{z}$}

Amaç: Kolorektal kanser cerrahisi sonrası oluşan anastomoz kaçağının ve buna bağlı gelişen mortalitenin yaş ile ilişkisini araştırmaktır.

Materyal ve Metod: Ocak 2013-Aralık 2018 tarihleri arasında kolorektal kanser nedeniyle elektif şartlarda rezeksiyon ve anastomoz yapılan hastaların verileri retrospektif olarak değerlendirildi. Hastalar, <65 yaș (Grup 1), $\geq 65$ yaș (Grup 2) olmak üzere iki gruba ayrıldı. Hastaların demografik özellikleri, perioperatif riskler, hastalıklı kolon segmenti, neoadjuvan kemoradyoterapi alıp almaması ve uygulanan cerrahi prosedür (laparoskopik/açık) iki grup arasında irdelendi. Çalışmanın birinci sonuç ölçütü ameliyattan sonra 30 gün içerisinde gelişen anastomoz kaçağı idi. İkinci çalışma ölçütümüz ise postoperatif 30 gün içerisinde anastomoz kaçağına bağlı gelişen mortalite idi.

Bulgular: Çalışmaya 358 hasta dahil edildi. Hastaların \%60.6'sı erkek, \%39.4'ü kadın idi ve

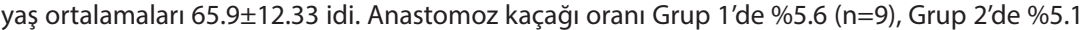
$(n=10)$ olarak saptandı $(p=0.283)$. Anastomoz kaçağına bağlı gelişen toplam mortalite $\% 1.95$ idi. Grup 1'de anastomoz kaçağına bağlı mortalite \%0.6 iken Grup 2'de \%3.06 idi ( $p=0.043$ ).

Sonuç: Kolorektal kanser cerrahisi sonrası yaşın anastomoz kaçağı için risk faktörü olmadığını ancak anastomoz kaçağı sonrası mortalitenin ileri yaşı hastalarda arttığını göstermektedir.

Anahtar sözcükler: Anastomoz kaçağı; Yaşlı; Kolorektal kanser; Mortalite 


\section{INTRODUCTION}

Colorectal cancer ranks third among all cancers (1). The elderly population has significantly increased in recent years, and advanced age is a risk factor for the development of colorectal cancer (2). This increase is expected to continue owing to the initiatives toward increasing life expectancy and early diagnosis $(3,4)$. Of the patients diagnosed with colorectal cancer, $50 \%$ are aged $\geq 60$ years and postoperative mortality and morbidity is high in elderly patients owing to the presence of comorbid diseases (5). However, curative resection is the main treatment for colorectal cancer. Studies have shown that advanced age is not a contraindication for colorectal cancer surgery (CCS) and that CCS can be safely performed and overall survival is similar to life expectancy $(6,7)$. Although the cause remains unclear, anastomotic leakage $(A L)$ that develops following colorectal surgery is one of the major complications that is worrisome because of the increased morbidity and mortality as well as of their negative impact on the duration of hospital stay and functional and oncologic outcomes. However, studies investigating this subject in elderly patients are limited in literature. Whether age plays a role in $A L$ remains a matter of debate. Gessler B et al. have reported that AL does not correlate with age (8). Ureyen $O$ et al. have reported that the risk of $A L$ is higher in the elderly population (9). In contrast, Park JS et al. have reported that $A L$ is more common in the young population (10). Following colorectal surgery, AL is observed in $3 \%-28 \%$ of cases and is responsible for one-third of postoperative mortality (11). However, AL-related mortality is higher in elderly patients (12). Unfortunately, there is a paucity of data on this subject in literature. The present study aimed to investigate the relationship between age

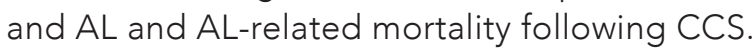

\section{MATERIALS AND METHOD}

\section{Study design}

Data of patients who underwent elective resection and anastomosis for colorectal cancer in our clinic between January 2013 and December 2018 were retrospectively evaluated by reviewing the hospital database system and patient files. The present study was approved by the ethics committee of our hospital (2019/514/148/13).

Patients who did not undergo curative resection for colorectal cancer, those treated with Hartmann procedure or transanal local resection, those treated only with deflective stoma, those with missing data, and those who were operated under emergency conditions were excluded from the study. According to the American Joint Commission on Cancer (AJCC) TNM staging (13), patients with middle and lower rectal carcinoma other than $\mathrm{T} 1$ received neoadjuvant chemoradiotherapy (CRT) and total mesorectal excision was performed 8-10 weeks after CRT. A protective ileostomy was routinely performed following anastomosis below the peritoneal reflection in patients with rectal tumor who received neoadjuvant CRT. The decisions were made on a case-by-case basis for the remaining patients with upper rectal and colonic tumors considering their general condition and depending on technical issues encountered both during anastomosis and during the perioperative period. In our study, all patients who underwent surgery for colorectal cancer under elective conditions underwent resection and anastomosis with or without stoma.

\section{Outcome measure and other variables}

Patients included in the study were divided into two groups: patients aged $<65$ years (Group 1) and those aged $\geq 65$ (Group 2). Demographic characteristics, perioperative risks, diseased colonic segment, neoadjuvant CRT, and surgical procedure (laparoscopic/open) were evaluated between both groups. The primary endpoint of the study was $A L$ that developed within 30 days postoperatively. The secondary endpoint was ALrelated mortality within 30 days postoperatively.

\section{Statistical analysis}

SPSS 22.0 (IBM Corporation, Armonk, New 
York, United States) software was used for the analysis of variables. Descriptive data were presented as percentages, mean \pm standard deviation. Normality testing (Kolmogorov Sminov) was performed to determine whether the data followed a Gaussian distribution or not. Continuous variables in two independent groups were compared with Student $t$ test or the Mann-Whitney U test. Categorical variables were compare by Pearson's chi-square test or Fisher's exact test. A binary logistic regression analysis was performed to identify potentially risk factors for age groups. A $p$ value $<0.05$ was considered as statistically significant.

\section{RESULTS}

\section{Study population}

The study included 358 patients who underwent elective resection and anastomosis for colorectal cancer. Of these patients, $60.6 \%$ were male, $39.4 \%$ were female, and mean age was $65.9 \pm 12.33$. Tumors were most commonly localized in the rectum (23.7\%) and sigmoid colon (23.7\%).

\section{Anastomotic leakage}

Overall incidence of $A L$ in the study group was $5.3 \%(n=19)$. The rate of $A L$ was $5.6 \%(n=9)$ in Group 1 and 5.1\% ( $n=10)$ in Group $2(p=0.283)$. Age was not found to have a significant influence on the development of AL. Of the 19 patients that developed AL, 9 had stoma and 10 had no stoma $(p=0.78)$.

When patient files and database were reviewed for the treatment and management of the patients with $A \mathrm{~L}$, of 9 patients with protective stoma that developed $A L, 3$ were detected, on an average, on the 5th day of the postoperative follow-up period (4-7) and 6 were detected when they presented to the General Surgery outpatient clinic with symptoms of abdominal pain and fever on average on the 11th day after discharge from the hospital (7-19). Conversely, in all patients without protective stoma that developed $\mathrm{AL}$, diagnosis was made by means of clinical observation and imaging methods on the 4th day (3-7) of their postoperative follow-up period. Only two patients with protective stoma who developed $\mathrm{AL}$ required relaparotomy after the first operation. Of these 9 patients, 3 died in the postoperative period, 4 underwent ileostomy closure without any problems after completion of oncological treatment, and in the remaining 2 patients with anastomotic stricture, ileostomy was not closed in 1 patient and the other patient underwent the Hartmann procedure after ileostomy closure owing to acute renal failure. It was observed that relaparotomy was required in 8 out of 10 patients without protective stoma that developed AL. Of these patients, 6 underwent Hartman procedure and 2 underwent ileostomy operation. Endoscopic clipping was performed in 2 patients who did not require relaparotomy and showed no evidence of peritonitis on physical examination.

\section{Mortality}

Overall mortality was $0.6 \%(n=1)$ in Group 1 and $4.1 \%(n=8)$ in Group $2(p=0.037)$. AL-related mortality occurred in only one patient in Group 1 , whereas it occurred in 6 out of 8 patients in Group 2. Of these 6 patients, protective stomas were performed in 3 patients, whereas it was not performed in the remaining 3. The total AL-related mortality was $2 \%$; AL-related mortality was $0.6 \%$ in Group 1 and 3.1\% in Group 2 ( $p=0.043$ ).

According to age groups, in favor of advanced age group hypertension, congestive heart failure $(\mathrm{CHF})$, coronary artery disease (CAD), chronic obstructive pulmonary disease (COPD), high American Society of Anesthesiologists (ASA) score, and presence of protective stoma found statistically significant (Table 1). There was a significant difference between both groups in terms of tumor $\mathrm{N}$ stage, number of lymph nodes removed, and number of metastatic lymph nodes (Table 2). Binary logistic regression analysis showed that $C H F, C A D$, presence of protective stoma, high ASA score, and number of metastatic lymph nodes significantly correlated with age (Table 3). 
Table 1. Clinical characteristic of patients according to age groups.

\begin{tabular}{|c|c|c|c|c|c|}
\hline & & $\begin{array}{r}\text { Group } 1 \\
\text { (<65 years) } \\
\mathrm{n}(\%)\end{array}$ & $\begin{array}{r}\text { Group } 2 \\
\text { ( } \geq 65 \text { years) } \\
n(\%)\end{array}$ & $\begin{array}{l}\text { Total } \\
\mathrm{n}(\%)\end{array}$ & $p$ \\
\hline Age (average $\pm \mathrm{sd}$.) & & $54.52 \pm 6.03$ & $75.11 \pm 7.46$ & $65.79 \pm 12.33$ & $0.001^{\star \star}$ \\
\hline \multirow{2}{*}{ Sex } & Female & $55(34.0)$ & $86(43.9)$ & 141(39.4) & \multirow{2}{*}{$0.056^{\star}$} \\
\hline & Male & $107(66.0)$ & $110(56.1)$ & $217(60.6)$ & \\
\hline ASA(average \pm sd.) & & $2.29 \pm 0.46$ & $2.81 \pm 0.40$ & $2.57 \pm 0.49$ & $0.001^{* *}$ \\
\hline \multirow{2}{*}{$\begin{array}{l}\text { Anastomotic } \\
\text { leakage }\end{array}$} & No & 153(94.4) & $186(94.9)$ & $339(94.7)$ & \multirow{2}{*}{$0.283^{*}$} \\
\hline & Yes & $9(5.6)$ & $10(5.1)$ & $19(5.3)$ & \\
\hline \multirow{7}{*}{ Tumor location } & Ascending Colon & $23(14.2)$ & $31(15.8)$ & $54(15.1)$ & \multirow{7}{*}{$0.849 *$} \\
\hline & Descending Co-lon & $0(0.0)$ & $9(4.6)$ & $9(2.5)$ & \\
\hline & Rectosigmoid & $41(25.3)$ & $35(17.9)$ & $76(21.2)$ & \\
\hline & Rectum & $47(29)$ & $38(19.4)$ & $85(23.7)$ & \\
\hline & Sigmoid & $24(14.8)$ & $53(27)$ & $77(21.5)$ & \\
\hline & Splenic Flexure & $1(0.6)$ & $0(0.0)$ & $1(0.3)$ & \\
\hline & Transverse Co-lon & $26(16)$ & $30(15.3)$ & $56(15.6)$ & \\
\hline \multirow{2}{*}{$\begin{array}{l}\text { Protective } \\
\text { ileostomy }\end{array}$} & No & $126(77.8)$ & $171(87.2)$ & $297(83.0)$ & \multirow{2}{*}{$0.018^{*}$} \\
\hline & Yes & $36(22.2)$ & $25(12.8)$ & $61(17.0)$ & \\
\hline \multirow{2}{*}{ Mortality } & No & $161(99.4)$ & 188(95.9) & $349(97.5)$ & \multirow{2}{*}{$0.037^{*}$} \\
\hline & Yes & $1(0.6)$ & $8(4.1)$ & $9(2.5)$ & \\
\hline \multirow{2}{*}{$\begin{array}{l}\text { Intestinal } \\
\text { preparation }\end{array}$} & No & $0(0.0)$ & $2(1)$ & $2(0.6)$ & \multirow{2}{*}{$0.197^{\star}$} \\
\hline & Yes & $162(100.0)$ & 194(99.0) & $356(99.4)$ & \\
\hline \multirow{7}{*}{ Comorbidity } & Diabetes & $35(21.6)$ & $53(27.0)$ & $88(24.6)$ & $0.234^{\star}$ \\
\hline & Hypertension & $31(19.1)$ & 103(52.6) & 134(37.4) & $0.001^{*}$ \\
\hline & Heart Failure & $3(1.9)$ & $31(15.8)$ & $34(9.5)$ & $0.001^{*}$ \\
\hline & $\mathrm{Ml}$ & $3(1.9)$ & $0(0.0)$ & $3(0.8)$ & $0.056^{\star}$ \\
\hline & COPD & $6(3.7)$ & $20(10.2)$ & $26(7.3)$ & $0.018^{\star}$ \\
\hline & CAD & $2(1.2)$ & $17(8.7)$ & $19(5.3)$ & $0.002^{\star}$ \\
\hline & CKF & $4(2.5)$ & $9(4.6)$ & $13(3.6)$ & $0.285^{\star}$ \\
\hline \multirow{2}{*}{ Blood Transfusion } & No & 133(82.1) & $148(75.5)$ & $281(78.5)$ & \multirow{2}{*}{$0.131 *$} \\
\hline & Yes & $29(17.9)$ & $48(24.5)$ & $77(21.5)$ & \\
\hline \multirow[b]{2}{*}{$\begin{array}{l}\text { Operation } \\
\text { technique }\end{array}$} & Laparoscopic & $46(28.4)$ & $40(20.4)$ & $86(24.0)$ & \multirow[b]{2}{*}{$0.078^{\star}$} \\
\hline & Open & 116(71.6) & $156(79.6)$ & $272(76.0)$ & \\
\hline
\end{tabular}

*Chi-square test (Fisher's exact test). ** Mann-Whitney U analysis.Sd: Standard deviation.

ASA: American Society of Anesthesiologists, MI: Myocardial infarction, COPD: Chronic obstructive pulmonary disease, CAD: Coronary artery disease, CKF: Chronic kidney failure. 


\section{DISCUSSION}

The number of people aged $\geq 60$ and is estimated to exceed 2 billion by 2050 (14). There is no consensus on the age limit in the definition of the elderly (15). The threshold of 65 years used in our study was in accordance with the elderly definition of the World Health Organization, although it would not completely reflect the physical decline associated with advanced age (16). Advanced age is a risk factor for the development of colorectal cancer, in addition to being the most important risk factor for postoperative mortality and morbidity (5). With increasing elderly population, there is an emerging need of recognizing specific risks associated with surgery (17). However, studies conducted to date have not adequately addressed the relationship between age and $A L$, which is one of the most serious complications of colorectal surgery, and AL-related morbidity and mortality. In the present study, we aimed to investigate the relationship between age and $A L$, as well as $A L-$ related mortality, following CCS performed under elective conditions.

It has been reported that $50 \%$ of the patients diagnosed with colorectal cancer are aged $\geq 60$ years (5). In our study, elderly patients constituted $54.7 \%$ of the study sample. In literature, male sex, high ASA score, CAD, COPD, steroid use, and diabetes mellitus have been reported as independent risk factors for $\mathrm{AL}(15,18)$. In our

Table 2. TNM stage, number of lymph nodes excised and neoadjuvant CRT in the groups.

\begin{tabular}{|c|c|c|c|c|c|}
\hline & & $\begin{array}{r}\text { Group } 1 \\
n(\%)\end{array}$ & $\begin{array}{r}\text { Group } 2 \\
n(\%)\end{array}$ & $\begin{array}{l}\text { Total } \\
\mathrm{n}(\%)\end{array}$ & $p$ \\
\hline \multirow{5}{*}{ T stage } & TO & $3(1.9)$ & $3(1.5)$ & $6(1.7)$ & \multirow{5}{*}{$0.512^{\star}$} \\
\hline & $\mathrm{T} 1$ & $22(13.6)$ & $20(10.2)$ & $42(11.7)$ & \\
\hline & $\mathrm{T} 2$ & $106(65.4)$ & 143(73.0) & $249(69.6)$ & \\
\hline & T3 & $6(3.7)$ & $3(1.5)$ & $9(2.5)$ & \\
\hline & $\mathrm{T} 4$ & $25(15.4)$ & $27(13.8)$ & $52(14.5)$ & \\
\hline \multirow{3}{*}{ N stage } & No & $74(45.7)$ & 109(55.6) & 183(51.1) & \multirow{3}{*}{$0.048^{\star}$} \\
\hline & N1 & $41(25.3)$ & $51(26)$ & $92(25.7)$ & \\
\hline & N2 & $47(29)$ & $36(18.4)$ & $83(23.2)$ & \\
\hline \multirow{2}{*}{ TNM stage } & $<3$ & $72(44.4)$ & $105(53.6)$ & 177(49.4) & \multirow{2}{*}{0.359} \\
\hline & $\geq 3$ & $90(55.6)$ & $91(46.4)$ & $181(50.6)$ & \\
\hline \multirow{2}{*}{$\begin{array}{l}\text { Neoadjuvant } \\
\text { therapy }\end{array}$} & No & $120(74.1)$ & $160(81.6)$ & $280(78.2)$ & \multirow{2}{*}{0.085} \\
\hline & Yes & $42(25.9)$ & $36(18.4)$ & $78(21.8)$ & \\
\hline $\begin{array}{l}\text { Number of } \\
\text { lymph nodes re- } \\
\text { moved(average } \\
\pm \text { sd.) }\end{array}$ & & $19.77 \pm 8.99$ & $17.56 \pm 9.30$ & $18.56 \pm 9.21$ & $0.024^{\star *}$ \\
\hline $\begin{array}{l}\text { Number of } \\
\text { metastatic lymph } \\
\text { nodes(average } \pm \\
\text { sd.) }\end{array}$ & & $3.45 \pm 5.90$ & $1.79 \pm 2.90$ & $2.54 \pm 4.58$ & $0.001^{\star \star}$ \\
\hline
\end{tabular}

CRT. Chemoradiotherapy, TNM.T: Tumor, N:Node, M: Metastasis. 
Table 3. Binary logistic regression analysis of according to the ages groups.

\begin{tabular}{|l|r|r|c|}
\hline Variables & Odds ratio & $95 \%$ Cl & p value \\
\hline Preventive ileostomy & 5.893 & 2.631 to 13.199 & 0.001 \\
\hline ASA & 9.439 & 4.639 to 19.206 & 0.001 \\
\hline CAD & 0.229 & 0.043 to 1.210 & 0.043 \\
\hline Heart failure & 0.082 & 0.021 to 0.326 & 0.001 \\
\hline Number of metastatic lymph node & 0.875 & 0.777 to 0.985 & 0.028 \\
\hline Mortalite & 0.153 & 0.0002 to 0.111 & 0.006 \\
\hline
\end{tabular}

$\mathrm{Cl}$ : Confidence Interval.Compared to general and spinal Anesthetic Technique ( $p=0.0017)$, Compared to spinal and combined spinal-epidural Anesthetic Technique $(p=0.016)$, c. Compared to general and spinal Anesthetic Technique $(p=0.004)$

study, binary logistic regression analysis showed that $\mathrm{CHF}, \mathrm{CAD}$, high ASA score, and number of metastatic lymph nodes significantly correlated with advanced age. Although these predictive factors related to $A L$ are more significant in elderly patients, it is a matter of debate whether age plays a role in $\mathrm{AL}$ development. In the study by the Danish Colorectal Cancer Group and the American College of Surgeons National Surgical Quality Improvement Program, increasing age has been reported to correlate with a decrease in the rate of AL (19). They attributed this finding to both more meticulous preoperative preparation and surgical intervention in the elderly patients. In contrast to these findings, another study has reported an increasing incidence of $A L$ with increasing age (20). In a meta-analysis of 16 studies involving a total of 4,479 cases, no significant difference was reported between the elderly and young patients in terms of the risk of developing $A L$ (21).

The rate of $A L$ following colon resection due to benign and malignant causes is 3.0\%-6.4\% $(22,23)$. Rencuzogulları et al. have studied a cohort of 10,392 cases aged $>65$ years that underwent colon resection due to benign and malignant causes and reported that the rate of $\mathrm{AL}$ was $3.2 \%$ (15). In 45,488 patients who underwent surgery for colorectal cancer, Zaimi et al. have reported an incidence of $6.4 \%$ for $A L$ in patients aged $<60$ years, $5.5 \%$ in patients aged $60-69$ years, $5.4 \%$ in patients aged $70-80$ years, and $4.9 \%$ in patients aged $\geq 80$ years (12).

In our study, the overall AL incidence was 5.3\% $(n=19)$ in patients who underwent elective surgery for colorectal malignancy. The rate of $A L$ was found to be $5.6 \%(n=9)$ in patients aged $<65$ years and $5.1 \%(n=10)$ in those aged $\geq 65$ years. Age was not a significant factor for the development of AL. Of the 19 patients that developed $A L$, stoma was performed in 9 and it was not performed in 10 ( $p$ $=0.780$ ). In the present study, we found that stoma had no protective effect against AL. This result was consistent with that observed previously (24).

Effective treatment is essential when $A L$ is diagnosed. Early decision of surgery is the most important factor that reduces mortality. Especially $A L$, which develops in patients with protective stoma, is mostly asymptomatic, and medical supportive therapy is often sufficient. In patients with extraperitoneal anastomosis who do not have signs of peritonitis during examination, special drains inserted into the fistula tract following endoscopic debridement and negative-pressure 
aspiration facilitate healing in $A L$ and reduce the need for a second surgical intervention (8). In cases without protective stoma, proximal fecal diversion can be performed, and in cases with extensive peritonitis and those in which anastomosis is fully separated, the Hartmann procedure is essential (8). Of 9 patients with protective stoma included in this study, 2 were followed up with an endosponge, 4 with percutaneous drainage, 1 with stent, and 2 with only medical therapy. Of 10 patients without protective stoma that developed $A L$, relaparotomy was performed in 8 patients, 6 of whom underwent the Hartman procedure and 2 underwent ileostomy construction. Endoscopic clips were placed in the other 2 patients.

$\mathrm{AL}$ following colorectal surgery is responsible for one-third of postoperative mortality (11). However, AL-related mortality is higher in elderly patients (12). A multicenter study has reported four times higher mortality following $\mathrm{AL}$ in elderly patients compared with young patients (25). In the study by Zaimi et al., mortality following $\mathrm{AL}$ in patients who underwent surgery for colorectal cancer was reported to be $1.3 \%$ in patients aged $<60$ years, $4.8 \%$ in patients aged $60-69$ years, $12.3 \%$ in patients aged $70-80$ years, and $27.0 \%$ in patients aged $\geq 80$ years (12).

In our study, the overall AL-related mortality was $1.95 \%$. AL-related mortality was $0.6 \%$ in patients aged $<65$ years and $3.06 \%$ in patients aged $\geq 65$ years $(p=0.043)$. In our study, patients aged $\geq 65$ years exhibited higher number of comorbidities. This was related to the high ASA score of the elderly patients $(p=0.001)$. The significant difference between mortality of the two groups can be attributed to comorbidities in elderly patients; moreover, not consenting to a second surgery following $A L$ is a possible reason. In our study, protective stoma was more common among the patients aged $<60$ years. This is attributable to the higher number of patients with rectal and rectosigmoid localization in this group compared with that in the group of patients $\geq 60$ years.
In our clinic, post-anastomosis protective ileostomy below the peritoneal reflection is routinely performed in patients with rectal tumor receiving neoadjuvant CRT. The decision is made on a case-by-case basis for the remaining patients with upper rectal and colonic tumors considering their general condition and depending on technical issues encountered both during anastomosis and during the perioperative period. Protective stomas do not reduce the occurrence of $A L$; however, they reduce the severity of AL-related septic findings and facilitate the treatment of leakages using palliative methods (24).

The reason for low mortality in our study compared with that reported in literature is that the studies in the literature are heterogeneous studies including patients operated under both emergency and elective conditions. However, our study consisted of patients who were operated under elective conditions involving preoperative preparation. We believe that this difference allowed us to obtain more significant results compared to other studies.

In our study, higher ASA score was observed in elderly patients, and AL-related mortality was significantly higher in these patients. It has been shown that laparoscopic surgery for colorectal cancer is as safe in elderly patients as it is in younger patients (21). Our results are consistent with those in the literature. In our study, right hemicolectomy due to right-sided colon-localized tumor exhibited the lowest rate of $\mathrm{AL}$ in both groups. The incidence of AL was mostly observed in surgeries related to rectum-localized tumors.

In conclusion, the present study shows that age is not a risk factor for AL following CCS; however, there is an increase in AL-related mortality in elderly patients.

\section{CONFLICT OF INTEREST}

All authors declare that there is not any conflict of interest. 


\section{REFERENCES}

1. Araghi M, Soerjomataram I, Jenkins M, et al. Global trends in colorectal cancer mortality: projections to the year 2035. Int J Cancer 2019;144(12):2992-3000 doi:10.1002/ijc.32055. (PMID:30536395).

2. Verweij NM, Schiphorst $A H$, Maas $H A$, at al. Colorectal cancer resections in the oldest old between 2011 and 2012 in the Netherlands. Ann SurgOncol2016;23(6):1875-82. (PMID:26786093).

3. Jemal A, Bray F, Center MM, Ferlay J, Ward E, Forman D. Global cancer statistics. CA Cancer J Clin 2011;61(2):69-90. (PMID:21296855).

4. Bretthauer M. Colorectal cancer screening. J Intern Med 2011;270(2):87-98. (PMID:21575082).

5. Turrentine FE, Wang $H$, Simpson VB, Jones RS. Surgical risk factors, morbidity, and mortality in elderly patients. J Am CollSurg 2006;203(6):865-77. (PMID:17116555).

6. de Buck van Overstraeten A, Stijns J, Laenen A, Fieuws S, Wolthuis AM, D'Hoore A. Is colorectal surgery beyond the age of 80 still feasible with acceptable mortality? An analysis of the predictive value of CRPOSSUM and life expectancy after hospital discharge. Colorectal Dis 2017;19(1):58-64. (PMID:27717124).

7. Yap R, Oliva K, Wilkins S, McMurrick PJ. Colorectal cancer surgery in the very elderly: nonagenarians. Dis Colon Rectum 2016;59(6):501-7. (PMID:27145306).

8. Gessler B, Eriksson O, Angenete E. Diagnosis, treatment, and consequences of anastomotic leakage in colorectal surgery. Int J Colorectal Dis 2017;32(4):549-56. (PMID:28070659).

9. Ureyen $O$, Ilhan $E$, Dadalı E, et al. Evaluation of factors associated with anastomotic leakage in colorectal surgery. Turk J Colorectal Dis 2018;28(3):129-35. doi: https://doi.org/10.4274/tjcd.53386. (PMID: 29881234)

10. Park JS, Huh JW, Park YA, et al. Risk factors of anastomotic leak age and long-term survival after colorectal surgery. Medicine (Baltimore) 2016;95:2890. (PMID: 26937928).

11. Macarthur DC, Nixon SJ, Aitken RJ. Avoidable deaths still occur after large bowel surgery. Scottish Audit of Surgical Mortality, Royal College of Surgeons of Edinburgh. Br J Surg 1998;85(1):80-3. (PMID:9462390).

12. Zaimi I, Sparreboom CL, Lingsma HF, et al. The effect of age on anastomotic leakage in colorectal cancer surgery: A population-based study. J SurgOncol 2018;118(1):113-20. (PMID:29878360).

13. Edge SB, Byrd DR, Compton CC et al. Anus, In: Edge
SB, Byrd DR, Compton CC, Fritz AG, Greene FL, Trotti A (Eds). AJCC Cancer Staging Manual. Seventh Edition, Springer-Verlag, New York, USA 2010, pp 165-73.

14. Koopman R, van Loon LJ. Aging, exercise, and muscle protein metabolism. J ApplPhysiol 2009;106(6):20408. (PMID:19131471).

15. Rencuzogullari A, Benlice C, Valente M, Abbas MA, Remzi FH, Gorgun E. Predictors of anastomotic leak in elderly patients after colectomy: Nomogram-based assessment from the American College of Surgeons National Surgical Quality Program ProcedureTargeted Cohort. Dis Colon Rectum 2017;60(5):52736. (PMID:28383453).

16. World Health Organization. Proposed working definition of an older person in Africa for the MDS Project. [Internet] Available from: https://www. who.int/healthinfo/survey/ageingdefnolder/en/. Accessed: 19.03.2019.

17. US Census Bureau Population Division. Percent distribution of the projected population by selected age groups and sex for the United States: 2015 to 2060 (NP2012-T3L). 2013.Washington DC: Government Printing Office. [Internet] Available from: https://www. census.gov/data/tables/2012/demo/popproj/2012summary-tables.html. Accessed: 19.03.2019.

18. Krarup $P$, Jorgensen $L$, Andreasen A, Harling $H$, Danish Colorectal Cancer Group. A nationwide study on anastomotic leakage after colonic cancer surgery. Colorectal Dis 2012;14(10):e661-7. (PMID:22564292).

19. Parthasarathy M, Greensmith M, Bowers D, GrootWassink T. Risk factors for anastomotic leakage after colorectal resection: a retrospective analysis of 17518 patients. Colorectal Dis 2017;19(3):288-98. (PMID:27474844).

20. Jung SH, Yu CS, Choi PW, et al. Risk factors and oncologic impact of anastomotic leakage after rectal cancer surgery. Dis Colon Rectum 2008;51(6):902-8. (PMID:18408971).

21. Hoshino N, Fukui Y, Hida K, Sakai Y. Short-term outcomes of laparoscopic surgery review and metaanalysis. Int J Colorectal Dis. 2019;34(3):377-86.doi: 10.1007/s00384-019-03234-0. (PMID:30649570).

22. Frasson $\mathrm{M}$, Flor-Lorente $\mathrm{B}$, Rodriguez $\mathrm{JL}$, et al. Risk factors for anastomotic leak after colon resection for cancer: multivariate analysis and nomogram from a multicentric, prospective, national study with 3193 patients. Ann Surg 2015;262(2):321-30. 
(PMID:25361221).

23. Masoomi H, Buchberg B, Dang P, Carmichael JC, Mills S, Stamos MJ. Outcomes of right vs. left colectomy for colon cancer. J GastrointestSurg 2011;15(11):20238. (PMID:21845511).

24. Gündes E, Cetin DA, Aday U, et al. Risk factors in anastomotic leaks after low anterior resection for rectal cancer and the effects of diverting stoma on clinical results.Turk J Colorectal Dis 2018;28:114-20. doi: 10.4274/tjcd.57704.

25. Bertelsen CA, Andreasen AH, Jørgensen T, Harling $\mathrm{H}$; Danish Colorectal Cancer Group. Anastomotic leakage after curative anterior resection for rectal cancer: short and long-term outcome. Colorectal Dis 2010;12(7):e76-81. (PMID:19438879). 